\title{
Capital versus Revenue: Receipts, Expenditures, Profits and Losses in Accounting and Taxation
}

\author{
Jit Bahadur K.C. \\ Associate Professor, Nepal Commerce Campus
}

\begin{abstract}
Objective - This article aims to enlighten the theory of capital and revenue nature receipt and expenditure in accounting and taxation.

Methodology/design/approach - Methodologically, this article adopts the descriptive research methods and qualitative approach based on the primary, secondary, and tertiary sources of information from Acts/laws, journals, reports, books, dictionary and encyclopaedia.

Finding and conclusion - The study found that the income tax Act of Nepal does not define the terms capital and revenue receipt and expenditure clearly, but clarifies provisions of non-business taxation assets of the individual persons and net gains from business assets or liabilities for the entity and gains from depreciable assets for both persons. Thus, we argue that it should define to avoid vagueness in the law. A simple tax law increases both tax revenue and evasion while vague decreases both.
\end{abstract}

Originality/value - This paper explicitly presents the state of capital and revenue receipt and expenditure in theory and practice. Thus, this paper furnishes facts about the stated subject and adds a new knowledge to the existing literature.

Keywords: Capital, revenue, receipts, expenditure, expense, gains, profit or loss.

\section{Introduction}

Capital means material wealth in the form of money or property which can be used to produce further wealth or income. Experts view that capital goods available for use as a factor of production. For example, Hodgson (2014) viewed, "Capital meant money investable or invested in business" (p. 1063). Other than the financial value, the term capital may also be used to denote the human capital, social capital, or natural capital if it studied broadly. In the same way, the term "revenue" denotes that gross income received by an entity. The International Accounting Standard Board (2003) 
defined, "Revenue is the gross inflow of economic benefits during the period arising in the course of the ordinary activities of an enterprise when those inflows result in increases in equity, other than increases relating to contributions from equity participants" ( $p$. 18.5). Furthermore, the term "revenue" also signifies that money, which comes into a business from the sale of goods or services or the income of a government from all sources, used to pay for a nation's expense, income or salary received from employment. Thus, metaphorically, the capital and revenue may be resorted as capital to a tree and income to its fruits.

Capital and revenue receipt and expenditure possess a significant role in both accounting and taxation, but the goal of these two concepts is different. The principal goal of the financial accounting is to furnish information to management, shareholders, creditors, and bankers or concerned persons or entities where the major responsibility of the accountant is to protect these parties from the misleading by accounting presentation. In contrast, the primary goal of the income tax system is an equitable collection of tax revenue to the government where the major responsibility of the tax official is to protect the public treasury. Directly and indirectly, thus, a system of financial accounting is the foundation of the income tax system in order to maintain the good governance.

Correspondingly, accounting and taxation always include some key issues. The issues of accounting mostly concern in obtaining the useful and relevant information to stakeholders in order to shape the managerial decision while the issues of taxation associate to ensure the revenue to the government, to reallocate the resources by redistribution of income and to manage effective fiscal device to retain good nexus between social and government policy.

The experts relating to accounting and taxation claim that the accounting value of income and expenses should be fair to obtain the exact amount of profit or taxable income in the taxation. For instance, if an entity recorded more or less revenue it impacts the profit and loss in accounting and taxable income in taxation by the same amount. Therefore, it requires understanding the exact notion of capital and revenue receipt and expenditure to get the fair value of the capital and revenue for the financial statements, (i.e., balance sheet, cash flow statement, income statement and change in equity) and taxable income for the taxation.

As explained differences of capital and revenue receipt, capital and revenue expenditure include crucial differences between them. Capital expenditure includes costs incurred on the acquisition of a fixed asset, purchase related expenditure and installation cost which increases the earning capacity of an existing fixed asset. The capital expenditure opposes to revenue expenditure. Normally, revenue expenditures are incurred for receiving or earning of income.

The exact figure of gains and profit or loss is not possible in accounting and taxation if the receipt and expenditure of capital and revenue figures are not placed properly. Thus, we tried to discuss the capital and revenue receipts and expenditure in this article in order to explain the condition of capital and revenue nature of receipts and expenditure to avoid the confusion and vagueness in the literature and to add the literature both on accounting and taxation. 


\subsection{Problem}

Experts believe that the income tax law is inherently too complex for even the most seasoned tax practitioner or academic professional to know everything. The complexity of taxation occurs either from the nature of the transaction or the expression of the laws. In this respect, Maples (2007) argued, "Tax complexity arising from the nature of the subject matter is potentially more difficult to address. One of the areas that causes complexity in this context is the capital-revenue distinction" (p. 3). The Income Tax Act of Nepal is not exceptional in this concern. As to the tax laws, it carries the income in an artificial construct which result the income tax law as a fiction.

The case of capital and revenue receipt and expenditure and their result of gains or profit or loss play a significant role in the accounting and taxation. For instance, the alteration of accounting entry of the capital expenditure if recorded in the revenue by mistake or intention, it shrinkage the amount of revenue and profit while capital receipt if recorded in the revenue that appreciates the profit. Consequently, the amount of capital gains fluctuates accordingly and neither capital gains and loss nor revenue profit and loss results the exact amount of these accounts.

In both accounting and taxation, the complexity is in the increasing trend year to year in the Nepalese financial and taxation system. According to the report of the Auditor General 2016, the amount of irregularity is $6.86 \%$ of the audited figures of rupees 1,295,449.20 million, while it was $4.38 \%$ in 2014 and $4.67 \%$ in 2015 (Fiftyfourth report of the Office of the Auditor General, Nepal, 2073), but this report does not include any irregularity of the private sector. In the same way, the irregularity and the discrepancy of the IRD was rupees 4,230 million of the fiscal year 2015/16 (IRD, 2073). It is also an increasing trend in Nepal.

There is a few literature on capital and revenue receipt and expenditure in Nepal consequently such complexity hindrances the understanding among the students, teachers, researchers, and policymakers as well. Thus, we tried to add a best literature through this writing in order to convey its idea and importance of the literature properly.

\subsection{Objectives}

The major objective of this study is to evaluate the capital-revenue receipts and expenditure and gains or profit or loss and the secondary objectives consist the following:

- To distinguish between capital and revenue receipts and expenditure,

- to enumerate and classify the different items of receipts and expenditure, and

- to identify the gains or profit and loss.

\subsection{Scope and limitations}

Both accounting and taxation are the crucial subject in this 21st century. Again they are more complicated by the concept of capital and revenue nature of receipt and expenditure which falls considerable important in accounting and taxation literature. 
The study enhances to obtain the additional knowledge in both subjects of accounting and taxation and provides information who wish to gains adequate knowledge about the capital and revenue receipt and expenditure. Thus, the students, teachers, researchers, chartered accountants and policy makers can take benefit from this study.

There is a few literature on the subject of the capital and revenue nature of receipt and expenditure. Thus, it is an additional cornerstone on that subject to communicate the literature. However, the literature bases on the available data and information.

\section{Review of literature}

This section is the succinct version of the previous studies relating to the capital and revenue receipt and expenditure. The aim of this section is to synthesise the subject in order to gain the subject and subjective knowledge and to find out the research gap. Thus, under this section, we discuss the availed literature in very succinct.

Table 1 Literature review of the capital and revenue receipts, expenditure, gains or profit and loss

\begin{tabular}{ll}
\hline Authors & Purpose \\
\hline Institute of & Distinction between \\
Chartered & capital and revenue \\
Accountants of & receipts \\
India (1980) &
\end{tabular}

Claim, description and suggestions

Capital expenditure: (a) to acquire of fixed assets, (i.e., assets of a permanent or a semi-permanent nature and that are held not for resale, but for the use to earning an income), (b) to add to the existing fixed assets, (c) to increase earning capacity of the business, (d) to reduce the cost of production, (e) to acquire a benefit of the enduring nature of a valuable right. The major impact of the alteration of the capital expenditure if treated into the revenue nature deflate the profit while revenue expense if treated into the capital expenditure it inflate the profit. Mehrotra (1983) $\quad \begin{aligned} & \text { Important of } \\ & \text { distinction }\end{aligned}$

Sally (2002)

International Accounting Standards Board (2003)
Search of possible link between taxation profit and profit of financial reporting

Difference in objectives

For the purpose of accounting and taxation, the distinction is important. However, Indian Income Tax Act 1961 does not make any distinction. Income tax levies on income, not on capital A number of developments in the evolution for the relationship between the rules for computing profits for tax and accounting purposes. Recently, the UK has put forward as an alternative to breaking the tax link, and a possible avenue for promoting the harmonization of taxation as well as financial reporting.

The objective of financial statement is to provide information about the financial position, performance and changes in financial position during the year and is to signify, "Fair value is the amount for which an asset could be exchanged, or a liability settled, between knowledgeable, willing parties in an arm's length transaction” (p. 18.5). 


\begin{tabular}{|c|c|c|}
\hline Authors & Purpose & Claim, description and suggestions \\
\hline$\overline{\text { Maples (2007) }}$ & $\begin{array}{l}\text { Lack in the } \\
\text { distinction in law }\end{array}$ & $\begin{array}{l}\text { New Zealand lacks the capital-revenue distinctions. } \\
\text { Therefore, it calculates the income of a person } \\
\text { based on the ordinary concepts of income. }\end{array}$ \\
\hline Simon (2009) & $\begin{array}{l}\text { Main cause of rules } \\
\text { and purposes }\end{array}$ & $\begin{array}{l}\text { Revenue, expenditure and profit should be same in } \\
\text { both commercial accounting and taxation, however, } \\
\text { they are different through purposes and subject to } \\
\text { different rules and purposes. }\end{array}$ \\
\hline $\begin{array}{l}\text { New Zealand } \\
\text { Treasury (2009) }\end{array}$ & Progressive taxes & $\begin{array}{l}\text { As to objective of equity, the progressive nature of } \\
\text { capital gains tax contributes to fairness. The study } \\
\text { suggested that owner occupied land and building } \\
\text { should be included in the capital gains tax base of } \\
\text { the individual. }\end{array}$ \\
\hline
\end{tabular}

There is a quite few literature on the capital and revenue receipt and expenditure for both academic as well as professional fields. Thus, we tried to add few new knowledge on the subject.

\section{Methodology and methods}

Methodology is the philosophical stance or the worldview that underlies and informs a style of research. Viewing the stated stance, this study by nature adopts a descriptive research, qualitative approach, observational and retrospective study using the variables of capital and revenue receipt and expenditure in order to centre their concepts. It employs three categorical sources of information: primary, secondary, and tertiary. As to the character of the study, they include acts, rules, law books, journals, concerned internet resources, law cases, accounting-law reports, dictionaries and encyclopaedia.

\section{Result and discussion}

In this section, we present both concepts: result and discussion due to the technical problem and causes. We chose convenient ways to distinguish the capital and revenue receipt, expenditure and gains or profit and loss. Thus, we presented the case in order of receipts, expenditures and gains or loss in the following sections.

\subsection{Distinction between capital and revenue receipts}

Experts argue that distinction between capital and revenue receipts play crucial role in accounting and taxation, although there is not a clear boundary. Mehrotra (1983) argued that there is not hard and fast rule to distinct the capital and revenue receipt and expenditure because one's capital receipt may be revenue to another. In this context, Black Law Dictionary (Black, 1990) defines that revenue is "Return, yield, as of land, profit, that which returns or comes back from an investment, the annual or periodical rents, profits, interests or issues of any species of property, real or personal, income" (p. 1428). Thus, based on experience, theory and practice of accounting and taxation, we tried to distinguish capital and revenue receipts as highlighted in the following table. 
Table 2. Distinction between capital and revenue receipts

\begin{tabular}{|c|c|}
\hline Capital receipts & Revenue receipts \\
\hline Nonrecurring in nature & - Recurring in nature \\
\hline $\begin{array}{l}\text { Sale of fixed capital (e.g., sale of fixed } \\
\text { property) or sale of capital (e.g., an } \\
\text { issuance of share). }\end{array}$ & $\begin{array}{l}\text { - Sale of circulating capital (e.g., trading } \\
\text { stock) or rendering the service. }\end{array}$ \\
\hline $\begin{array}{l}\text { Receipts of substitution of a source } \\
\text { of income (e.g., compensation against } \\
\text { termination of job). }\end{array}$ & $\begin{array}{l}\text { Receipts of substitution of an income (e.g., } \\
\text { a prize to an employee for his good service). }\end{array}$ \\
\hline $\begin{array}{l}\text { Receipts against surrender of certain } \\
\text { rights under an agreement (e.g., own right } \\
\text { handed over to others). }\end{array}$ & $\begin{array}{l}\text { - An agreement for the loss of futu } \\
\text { (e.g., if sum received from the br } \\
\text { agreement). }\end{array}$ \\
\hline $\begin{array}{l}\text { or unused assets of } \\
\text { t. }\end{array}$ & $\begin{array}{l}\text { - Sal } \\
\text { ren }\end{array}$ \\
\hline $\begin{array}{l}\text { Mostly in a lump sum, but may be in } \\
\text { instalment (e.g., fixed assets if sold in } \\
\text { instalment) basis. }\end{array}$ & $\begin{array}{l}\text { May be in lump sum (e.g., a person can } \\
\text { receive a mining royalty in a lump sum). }\end{array}$ \\
\hline currency of & $\begin{array}{l}\text { The devaluation/evaluation of currency } \\
\text { during the course of business. }\end{array}$ \\
\hline $\begin{array}{l}\text { Grant or subsidies if received from the } \\
\text { government for a particular purpose (e.g., } \\
\text { for a development purpose). }\end{array}$ & $\begin{array}{l}\text { Grant or subsidies received in order } \\
\text { to maintain the foreign competition or } \\
\text { assisting the business. }\end{array}$ \\
\hline 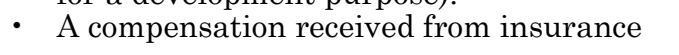 & \\
\hline $\begin{array}{l}\text { against the capital. } \\
\text { Not directly credited in profit \& loss } \\
\text { account. }\end{array}$ & $\begin{array}{l}\text { against the trading stock. } \\
\text { Directly credited in profit \& loss account. }\end{array}$ \\
\hline
\end{tabular}

\section{Source: Author's elaboration}

In economic view, Lachmann (1978) found two forms of capital: "The complementarity of the production plan as the direct result of entrepreneurial planning, and the complementarity of the structure of the economic system as a whole, based on the division of labour and capital, as the indirect result of the play of the market forces (p. 96)" which also are economically significant. Additionally, he also argued "Stock Exchange, which is a market not for physical capital goods, but for titles to them, an instrument for promoting consistent capital change" (p. 96).

A Dictionary of Accounting (2003) states that capital receipts are to treat as income for taxation purposes. For instance, if a landlord receives a lump sum on the granting of a lease that should be treated as revenue receipt. In the UK, the importance of the distinction between income and capital has diminished since income and capital have been charged at the same rate. However, prior to 1988 the capital was charged at $30 \%$, whereas the top rate of income tax was $60 \%$. The tax is calculated on the taxpayer's taxable income (i.e. gross income less any income tax allowances and deductions).

Revenue and income are considerably different in their use and meaning. For example, Fazal (2011) stated that revenue is the amount derived from the business activities or selling the main goods or services to its customers during the period while income loosely used to mean the total earnings of the business.

Thus, capital is the tree of fruit and capital receipt is the sales proceeds of that 
tree while revenue is the sales proceeds of the fruit.

\subsection{Distinction between capital and revenue expenditures}

Expenditure and expenses have different concepts in the literature of accounting and taxation. Specially, expenditure represents capital nature while expenses signifies revenue nature. For instance, if the utility of payment is availed during the same accounting year is called an expense, and if it is availed for more than one year, it is called expenditure. Thus, based on the different sources of literature, we afforded to distinguish the capital and revenue expenditure/expenses in the following table.

Table 3. Distinction between capital and revenue expenditure

\begin{tabular}{|c|c|}
\hline Capital expenditure & Revenue expenditure \\
\hline Nonrecurring in nature & - $\quad$ Recurring in nature. \\
\hline $\begin{array}{l}\text { Cost of acquisition (e.g., the cost of fixed } \\
\text { assets + purchase and installation related } \\
\text { costs). }\end{array}$ & $\begin{array}{l}\text { The cost of trading goods or its purchase } \\
\text { related expenses. }\end{array}$ \\
\hline - Lor & - Shor \\
\hline - Balance sheet items & $\begin{array}{r}\mathrm{M} \\
\mathrm{ac}\end{array}$ \\
\hline - A payment made for free from ca & - $\mathrm{A}_{1}$ \\
\hline - Cost c & - $\quad \begin{array}{ll}\text { la } \\
\mathrm{Al}\end{array}$ \\
\hline $\begin{array}{l}\text { - An e } \\
\text { capa }\end{array}$ & $\begin{array}{ll}\text { - An } \\
\text { rur }\end{array}$ \\
\hline $\begin{array}{l}\text { Capital nature for the acquirer and } \\
\text { revenue in the hand of recipient (e.g., a } \\
\text { school purchased a vehicle from the vehicl } \\
\text { dealer). }\end{array}$ & $\begin{array}{l}\text { rer } \\
\text { er (e.g., } \\
\text { ond }\end{array}$ \\
\hline $\begin{array}{l}\text { - An expenditure incurred for the fixed } \\
\text { assets (e.g., a bank purchased a safe box). }\end{array}$ & $\begin{array}{l}\text { the trading } \\
\text { imported safe }\end{array}$ \\
\hline $\begin{array}{l}\text { - An expenditure incurre } \\
\text { capital (e.g., cost of issu }\end{array}$ & $\begin{array}{l}\text { - An expenditure if incurred in raising loans } \\
\text { or debenture (e.g., loan related expenses). }\end{array}$ \\
\hline
\end{tabular}

Source: Author's elaboration

In a case of Pawn Kumar Ojha vs. Ministry of Finance, the Supreme Court of Nepal declared that an expenditure of repair and maintenance of the assets or property of the business to run it in a good and existing condition is the revenue expenses (Income tax: Repair and maintenance, 2062).

Yussof, Isa and Mohdali (2014) stated that both accounting and taxation distinguish between capital and revenue expenditure, however, some items considered as revenue expenditure in accounting are treated as capital expenditure in taxation, but they do not qualify for the capital allowance. As to the accounting system, all capital expenditures are subject to depreciation other than land. The expenses, which are not qualified as capital expenditure are classified as revenue expenditure.

Thus, capital expenditure is the expenditure for long-term goods and services which regards to earning the revenue income while revenue expenditure is the expense 
of either for goods or services which is sold to obtain the income.

4.3 Distinction between gains and profit or loss

Conceptually, profit and gains are considerably different nature and meaning in accounting and taxation. The major and easy distinction between profit and gains is that profit is the total earnings for a period of regular economic activities, whereas gains is an economic benefit derived by disposing an asset above its net book value or market value.

Usually, the profit derives different forms from different steps in the statement of accounting and taxation, (e.g., gross profit, operating profit, and net profit) while gains derives only two firms, (e.g., gains and net gains), but the term loss is the negative result of the income and signifies the single inverse meaning of profit or gains in both accounting and taxation. The following table highlights the event of gains, profit or loss in accounting and taxation which resulted from the transaction of capital and revenue receipt and expenditure/expenses.

Table 4. Distinction between capital and revenue gains, profit and loss

\begin{tabular}{lll}
\hline \multicolumn{1}{c}{ Capital nature gains or loss } & \multicolumn{1}{c}{ Revenue nature profit or loss } \\
\hline $\begin{array}{l}\text { Gains arises from the sale of capital asset } \\
\text { while loss arises from both capital and } \\
\text { revenue. }\end{array}$ & $\begin{array}{l}\text { Profit or loss arises from the sale of trading } \\
\text { stock or service of sales. }\end{array}$ \\
$\begin{array}{l}\text { Loss of money or misappropriation of the } \\
\text { bank account by the authorised person. }\end{array}$ & $\begin{array}{l}\text { Loss of the embezzlement cash by the } \\
\text { employees. }\end{array}$ \\
$\begin{array}{l}\text { Loss arisen from the strange person in the } \\
\text { business course. }\end{array}$ & $\begin{array}{l}\text { Loss sustained by theft committed by an } \\
\text { employee within the usual business hours. }\end{array}$ \\
$\begin{array}{l}\text { Loss of security deposit against to get an } \\
\text { agency business. }\end{array}$ & $\begin{array}{l}\text { Loss of cash in the way of deposit } \\
\end{array}$ \\
& $\begin{array}{l}\text { Loss from theft of stock in trade } \\
\text { Loss of earnest money by the way of lack of } \\
\end{array}$
\end{tabular}

Source: Author's elaboration

The profit or gains arise from the transaction of capital and revenue receipts and expenditure because, Fazal (2011) asserted that profit is the remaining value deducting after expense from revenue, which make the receipt of revenue possible and gains is what business earns on selling such assets which is not an inventory of the business.

K.C. (2007) stated that the Income Tax Act, 2002 of Nepal classify the capital receipts into the two categories, (i.e., received by individual or entities). If an individual receives net gains from capital receipts that is treated as capital gains tax at $10 \%$, while net gains from capital receipt of the entity is treated as business income and is taxable at the normal rate of corporate tax while capital loss can be deducted from capital gains only. The capital loss never be deducted from the revenue profit.

Holmes (2010) stated that recognition and classification of income and expenditure items of financial statements include problems. Among them, a serious problem is that the distinction between the ordinary revenue and capital gains nature of transactions. To some extent this issue is resolved in the period of the preparation of 
the financial statement using subjective judgement. The right judgment is essential to both sectors: accounting and taxation.

The circular of Inland Revenue Department (IRD) Nepal clarified the calculation method of the capital gains regarding the individual, but the policy regarding to the capital gains tax for the entity remained silent (2016).

Fundamentally, there is a significant difference between accounting profit and taxable profit and they are carried out using different methods of calculation. The following table summarises the differences of accounting profit and taxable profit (income).

Table 5. Distinction between accounting profit and taxable profit (income)

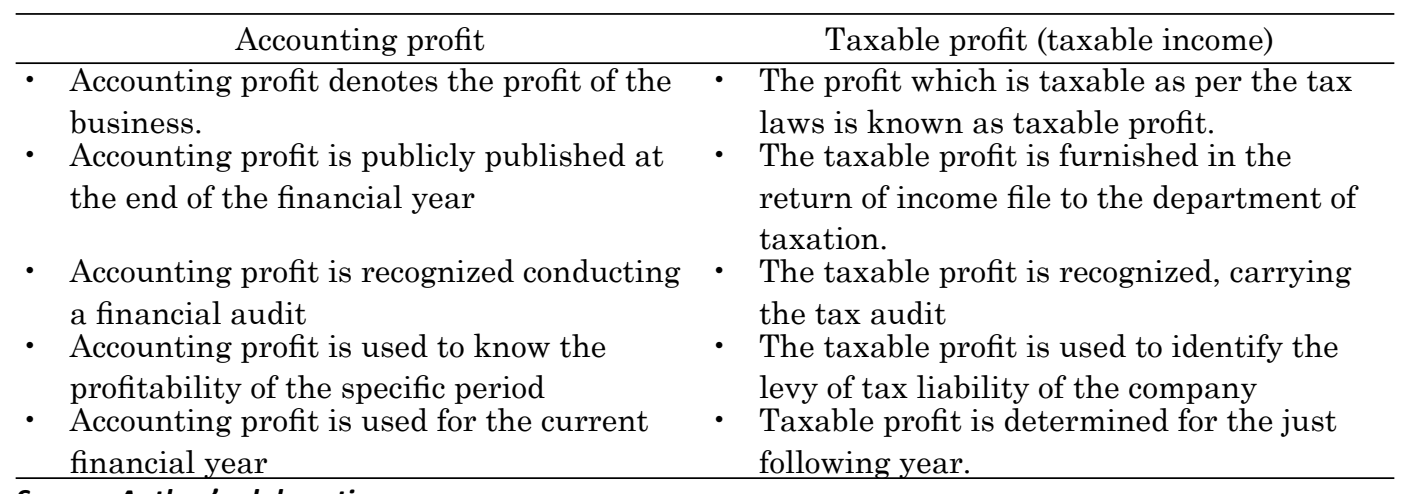

Source: Author's elaboration

Thus, both the gains and profit are significant in their place in accounting and taxation. The former denotes the excess of capital receipt than its capital expenditure while profit arises from revenue receipt than its expenses during a period or a year.

\section{Conclusion}

Inherently, income taxation is a complex subject among the various taxes. The difficulty comes to originate from either occurring of accounting transactions or believing the wrong practice or fundamental law enacted by the government. It is obvious that to determine the profit or gains or loss from any transaction or business or investment for the particular period, the first income should be exact in amount and then the expenditure/expense. The approximated receipt/income or expenditure/expense result approximated gains or profit or loss which result the wrong tax liabilities.

The distinction between gains and profit is that the gains arises from irregular activities or non-recurring transactions and are incidental to the business while profit derives from regular business activities or transactions, but both the activities increase the real capital of an owner. In other hand, loss occurs when a business earns few incoming than it's outgoing.

Fundamentally, the loss may category into: capital or revenue loss. The former does not affect that immediate value of taxable income because capital loss is deducted only from the capital gains while the latter effects immediate during the year.

Capital and revenue receipt play a vital role in accounting and taxation profit and they always alter the decision of the taxpayers. In an occasion, John of Kennedy

$$
\text { } 79 \text { }
$$


(Yablon, 2010) claimed, "The tax on capital gains directly affects investment decisions, the mobility and flow of risk capital . . . the ease or difficulty experienced by new ventures in obtaining capital and thereby the strength and potential for growth in the economy" (p. 96).

The Income Tax Act, 2002 of Nepal does not define that capital and revenue receipt and expenditure. It defines non-business taxation assets in the case of an individual person and net gains from disposal of business assets/liabilities in the case of an entity and net gains from disposal depreciable assets in the case of both. Thus, we suggest that it needs to define and clarify the capital receipts, and capital expenditure to avoid the confusion. Experts view that simple tax principles and laws enhance to collect more revenue and evasion while complex reduces both. However, simple tax principles and laws are preferable in order to make good redistribution, repricing and reallocation using more collected tax revenue.

\section{References}

Black, H. C. (1990). Black's law dictionary: Definitions of the terms and phrases of American and English jurisprudence, ancient and modern. St. Paul Minn: West Publishing Co.

Board of Studies of the Institute of Chartered Accountants of India. (1980). Capital and revenue expenditure, depreciation, provisions and reserve varification and valuation of assets and determination and verification of liabilities. In Auditing (pp. 2-4). New Delhi: The Institute of Chartered Accountants of India.

Fazal, H. (2011, March 31). What is the difference between revenue, income, profit, gains and return? Retrieved from PakAccountants.com: http://pakaccountants.com/differencerevenue-income-profit-gains-return/

Hodgson, G. M. (2014). What is capital? Economists and sociologists have changed its meaning: should it be changed back? Cambridge Journal of Economics, XXXVIII(5), 1063-1086. doi:10.1093/cje/beu013

Holmes, K. J. (2010). The classification of capital and revenue in accounting and the definition of income in the market-place. Wellington: Centre for Accounting, Governance and Taxation Research School of Accounting and Commercial Law Victoria University of Wellington. Retrieved from http://www.victoria.ac.nz/sacl/cagtr/publications.aspx

Income tax: Repair and maintenance, 2966 (Supreme Court, Nepal Chaitra 14, 2062).

Inland Revenue Department (IRD), Policy Analysis Section. (2016, July 26). The amended provision of the capital gain tax. Kathmandu: Government of Nepal, Ministry of Finance, Inland Revenue Department.

International Accounting Standard Board. (2003). International Accounting Standard IAS 18 revenue. In International Financial Reporting Standards: Incorporating International Accounting Standards and Interpretations (pp. 18.1-18.24). London: International Accounting Standard Board.

International Accounting Standards Board. (2003). International financial reporting standards. London: International Accounting Standards Board.

IRD. (2073). Annual Report 2072/073. Kathmandu: Government of Nepal, Ministry of Finance, Inland Revenue Department.

K.C., J. B. (2007). Tax laws and tax planning: Theory and practice. Kathmandu: Khanal Book 
Prakashan.

Lachmann, L. M. (1978). Capital and its Structure. San Francisco, California: Institute for Humane Studies Inc., and Cato Institute.

Maples, A. J. (2007). Tax complexity and the capital-revenue distinction-Lessons to be learnt from two recent New Zealand cases. Christchurch: Department of Accountancy, Finance \& Information Systems, University of Canterbury.

Mehrotra, H. C. (1983). Income tax law \& accounts. Agra: Sahitya Bhawan.

New Zealand Treasury. (2009). The taxation of capital gains. New Zealand: Victoria University of Wellington.

Office of the Auditor General. (2073). Fifty-fourth report of the Office of the Auditor General, Nepal. Kathmandu: Office of the Auditor General.

Oxford University. (2003). A Dictionary of accounting. Oxford: Oxford University Press.

Sally , A. (2002). Tax and accounting rules: some recent developments. European Business Review, XIV(2), 92-97. doi:10.1108/09555340210420064

Simon, J. (2009). The relationship between accounting and taxation. Streatham Court: University of Exeter.

Yablon, J. L. (Ed.). (2010). As certain as death: Quotation about taxes. U.S.A.: Tax Analysts.

Yussof, S. H., Isa, K., \& Mohdali, R. (2014). An analysis of the gap between accounting depreciation and tax capital allowance in Malaysia. Procedia - Social and Behavioral Sciences, 164 , 351 357. doi: 10.1016/j.sbspro.2014.11.087 